\title{
A CONCEPÇÃO DE MENTE EM JOHN SEARLE
}

\section{Matêus Ramos Cardoso}

\begin{abstract}
Graduação em Filosofia, pelo Centro Universitário de Brusque (UNIFEBE).licenciado em Filosofia, Ciências Humanas, Artes e Letras pelo Programa Especial de Formação Pedagógica, Universidade Católica de Brasília, UCB-DF. Pós-graduado em Ética e Filosofia - Faculdade Prominas/MG. Pós-Graduado em Ciências da Religião - Ucam - Instituto Pró-minas. Pós-Graduando em Psicopedagogia Clinica e Institucional - Ucam - Instituto Próminas. E-mail: teus33@yahoo.com.br
\end{abstract}

\section{RESUMO}

Apresenta os estudos da concepção de John Searle que considera que a mente existe realmente; que é uma característica do cérebro; que os estados mentais são causados pelo cérebro e têm lugar nele; que a maioria dos estados mentais são intencionais intrinsecamente; que são subjetivos e qualitativos, o que dificulta o seu estudo de um ponto de vista externo. Searle acredita que a consciência é um produto da evolução, produzida em cérebros altamente evoluídos, como uma vantagem evolutiva que possibilita a flexibilidade e criatividade nas ações. A mente ou a consciência é uma característica exclusiva de alguns sistemas biológicos dotados de sistemas nervosos complexos.

PALAVRAS-CHAVE: John Searle. Mente. Consciência

\section{THE CONCEPTION OF MIND IN JOHN SEARLE}

\begin{abstract}
It presents the studies of the conception of John Searle believes that the mind really exists; which is a feature of the brain; that mental states are caused by the brain and take place in it; that most mental states are intrinsically intentional; which are subjective and qualitative, which makes their study hard from an external point of view. Searle believes that consciousness is a product of evolution, produced in highly evolved brains, as an evolutionary advantage that enables flexibility and creativity in action. The mind or consciousness is a unique characteristic of some biological systems with complex nervous systems.
\end{abstract}

KEYWORDS: John Searle. Mind. Consciousness. 


\section{INTRODUÇÃO}

John Searle apresenta em seu estudo da mente uma solução que não compactua nem com o dualismo nem com o materialismo; ele tenta elaborar uma tese acerca da mente que supere esse antagonismo entre as duas perspectivas. Eis sua expressão: “... podemos aceitar os fatos óbvios da Física - por exemplo que o mundo é constituído de partículas físicas em campos de força - sem ao mesmo tempo negar os fatos óbvios de nossas próprias experiências - por exemplo, que somos todos conscientes e que nossos estados conscientes tem propriedades fenomenológicas irredutíveis bastante específicas."1 Sua tese, denominada de naturalismo biológico, não deixa de ser materialista, já que não postula a existência de uma substância para além do físico. Contudo, Searle pretende enaltecer os aspectos qualitativos e irredutíveis da consciência, aspectos esses que vem sendo, de maneira geral, ignorados pelas correntes predominantes na Filosofia da Mente contemporânea*.

Segundo o autor de A Redescoberta da Mente, não existe outra área da Filosofia Analítica contemporânea onde tantas coisas implausíveis sejam afirmadas como a Filosofia da Mente. Tanto o dualismo quanto o materialismo contém aspectos verdadeiros, mas são insuficientes, e acabam sendo falsos, em última análise. Isso porque desvalorizam ou negam uma das partes em detrimento à outra. $\mathrm{O}$ dualismo valoriza o aspecto intangível e imaterial da mente, enquanto que o materialismo enaltece a dependência dessa de um substrato físico.

O dualismo é menos valorizado contemporaneamente porque não é compatível com a visão científica de mundo. Sendo assim, o materialismo, em diferentes versões, é a corrente dominante. Sua crítica é mais fortemente direcionada a essa última perspectiva. Para Searle, o materialismo não é acolhido por ser verdadeiro, mas por ser compatível com a ciência. Assim ele se expressa: “Acredito que um dos pressupostos não declarados por trás do corrente conjunto de enfoques é que eles [os materialistas] representam as únicas alternativas cientificamente aceitáveis ao anticientificismo que acompanhou o dualismo tradicional, à crença na imortalidade da alma, o espiritualismo, etc." 2

\footnotetext{
${ }^{1}$ SEARLE, J. A Redescoberta da Mente. São Paulo: Martins Fontes, 1997, p. 45

* Podemos considerar como algumas das correntes materialistas importantes: funcionalismo; materialismo eliminativo; behaviorismo; entre outras.

${ }^{2}$ Ibid., p. 11.
} 
As críticas de Searle à "tradição materialista" - expressão com a qual ele quer designar as diferentes versões nas quais o materialismo se apresenta - são baseados no fato de que existem vários erros sendo repetidos nessas versões, contudo o principal deles é a pouca valorização da consciência e do aspecto qualitativo e subjetivo dos estados mentais. Isso porque a referida tradição tem como origem o behaviorismo, que procura estudar a mente ligando-a ao comportamento observável, já que isso garante a objetividade do estudo da mente. Entretanto, para Searle, essa tendência é objetivadora, que ignora e produz um afastamento da subjetividade e da consciência. Para Searle é certo que: "Nem toda a realidade é objetiva; parte dela é subjetiva." 3

\section{ARGUMENTO DO QUARTO CHINÊS}

Esse argumento do qual falamos rapidamente acima, quando nos referíamos à biografia de nosso autor, é um dos mais famosos de toda a sua obra. Trata-se de uma crítica que atinge diretamente os projetos dos pensadores da Inteligência Artificial* (IA). Entretanto, têm conseqüências que afetam também as teses dos pensadores ligados à corrente do funcionalismo e behaviorismo, já que esses usam o comportamento como elemento de compreensão dos fenômenos mentais. Eis o argumento de Searle na íntegra:

Suponha que eu estou trancado em um quarto e suponha que me dão um calhamaço de papel com um texto em chinês. Além disso, suponha que eu não conheça o idioma chinês, nem escrito nem falado, e que eu não seja sequer capaz de reconhecer escrita chinesa, ou seja, distingui-la, por exemplo, da japonesa ou de rabiscos sem significado. Suponha, agora, que além desse primeiro calhamaço fornecem-me - também em chinês - um segundo, contendo um roteiro com um conjunto de regras para correlacionar o segundo texto com o primeiro. As regras são em inglês e eu as compreendo tão bem como qualquer outro falante nativo de inglês. Isso me possibilita relacionar um conjunto de símbolos formais com o outro, e o que entendo por formal aqui é o que posso identificar os símbolos por seu formato. Nestas circunstâncias imagine também que me forneçam um terceiro calhamaço contendo símbolos em chinês junto com algumas instruções, outra vez em inglês, as quais me possibilitarão correlacionar elementos desse terceiro maço com os dois primeiros; estas regras me instruem como relacionar determinados símbolos em chinês com certos tipos de configurações e os

\footnotetext{
${ }^{3}$ Ibid., p.32.

* Nosso autor distingue duas formas de IA: a primeira é a IA fraca, para a qual o computador é um poderoso instrumento para o estudo da mente, já que permite simular processos cognitivos; para a segunda, a IA forte, um computador devidamente programado é uma mente, e que os programas explicam a capacidade cognitiva humana. $\mathrm{O}$ argumento do quarto chinês representa uma crítica a essa última forma de inteligência artificial.
} 
devolver como resposta a determinadas configurações dadas no terceiro calhamaço. Sem que eu saiba, as pessoas que me fornecem os textos com os referidos símbolos, denominam o primeiro bloco de "roteiro", o segundo de "história" e o terceiro de "questões". Ademais eles intitulam os símbolos devolvidos em resposta ao terceiro maço de "respostas às questões" e o conjunto de regras em inglês de "programa". Para complicar a história um pouquinho mais, imagine que estas pessoas também me forneçam histórias em inglês, as quais eu compreendo, e então questões em inglês sobre estas histórias, e eu as devolvo respondendo em inglês. Suponha, ainda, que depois de um tempo eu me saia tão bem ao seguir as instruções para manipulação dos símbolos em chinês e que programadores consigam escrever tão bem os programas do ponto de vista externo - isto é, do ponto de vista de alguém que esteja de fora do quarto do qual estou trancado - minhas respostas às questões são indistinguíveis de falantes nativos em chinês. Ninguém observando minhas respostas pode dizer que eu não falo uma palavra em chinês. Vamos também supor que minhas respostas às questões em inglês são indistinguíveis de outro falante nativo inglês - pela simples razão de que eu sou um falante nativo de inglês. Do ponto de vista externo, - na visão de alguém que lê as minhas respostas, - as respostas em chinês e inglês são igualmente satisfatórias. Mas no caso do idioma chinês, eu obtenho respostas manipulando símbolos formais em chinês, sem significação. No que diz respeito ao chinês, eu simplesmente me comportei como um computador; executei operações computacionais com base em elementos formalmente especificados. Para os propósitos do idioma chinês, eu sou simplesmente uma instanciação de um programa de computador. ${ }^{4}$

Para Searle, esse argumento evidencia a impossibilidade de um computador instanciar uma mente; bem como a impossibilidade dessa ser como um programa de computador. Isso porque os programas de computador funcionam apenas sintaticamente, enquanto as mentes vão além: compreendem o significado das sentenças, isto é, a sua semântica. Programas de computador não são mentes. ${ }^{5} \mathrm{O}$ argumento demonstra também que o comportamento não é garantia de atividade mental, e que, portanto, a mente não pode ser estudada suficientemente com base nesse.

O comportamento não é garantia de estados mentais conscientes, justamente porque a capacidade que o cérebro possui de causar comportamento é distinta da capacidade de produzir consciência ou mais propriamente, de estados mentais conscientes. Um sistema poderia ter consciência sem ter comportamento e ter comportamento sem consciência. Searle chama esse

\footnotetext{
${ }^{4}$ SEARLE, J. Mentes, Cérebros e Programas. Trad. Cléa Regina de Oliveira, In: TEIXEIRA, J.F. Cérebros, Máquinas e Consciência: uma introdução à filosofia da mente. São Carlos: EDUFSCar, 1996, p.66

${ }^{5}$ Cf. SEARLE, J. A Redescoberta da Mente. São Paulo: Martins Fontes, 1997, p. 286.
} 
princípio no qual o comportamento é irrelevante na ontologia dos estados mentais de princípio da independência de consciência e comportamento. ${ }^{6}$

\section{CARACTERÍSTICAS DA MENTE}

Segundo nosso autor, a mente humana faz com que vejamos o mundo com significado. O mundo, em si mesmo, não possui significado, mas nós o dotamos. Sendo assim, o grande mistério a ser desvendado é: Quais são as características da mente que faz nos relacionarmos com o mundo, de forma a nos sentirmos neste como seres livres e conscientes? Quais as características da mente que nos proporcionam essa espécie de representação do mundo?

Searle entende que os nossos estados mentais têm como características principais: são conscientes, intencionais, subjetivos, e acontecem no cérebro. Entretanto, a principal e mais fantástica característica dos estados mentais é certamente a de serem conscientes, uma vez que essa característica permite entender as demais. Se não estivéssemos conscientes sequer haveria possibilidade de compreensão dos estados mentais.

\section{LOCALIZAÇÃO CEREBRAL}

O primeiro pressuposto da teoria de Searle que precisamos trazer presente é o seguinte: toda a nossa vida mental é causada por processos que têm lugar no cérebro ${ }^{7}$. A mente não é uma substância independente do corpo, ela está em interação com o mesmo.

O argumento para defender que os processos mentais são localizados no cérebro é muito simples. Basta recordarmos como se dá o efeito da anestesia: ela impede que o estímulo nervoso (aspecto cerebral), proveniente do local onde que está provocando a dor, chegue até o cérebro e assim não há o sentimento de dor (aspecto mental). Outro exemplo que podemos trazer presente é o caso de pessoas que sofrem algum acidente e que, afetando de alguma forma o cérebro, acabam por ser portadores de alguma deficiência mental.

A mente não é algo separado do corpo, não é uma coisa. É uma característica presente em cérebros muito evoluídos como é o nosso caso; ela é uma característica do cérebro, assim como a liquidez é uma característica da água. Dessa forma, não é necessário um elo de ligação

${ }^{6}$ Cf. Ibid. p. 104.

${ }^{7}$ Cf. SEARLE, J. Mente, Cérebro e Ciência, Lisboa: Edições 70, 1984, p. 23 
entre mente e cérebro (ou mente e corpo), uma vez que, seguindo a analogia, não há nenhum elo de ligação entre as moléculas de água com a sua característica de ser líquida.

\section{CONSCIÊNCIA}

A consciência é a noção central quando nos referimos à mente, uma vez que todas as outras noções mentais só podem ser compreendidas a partir dela. Por isso, todo o nosso discurso sobre as características da mente está vinculado com a consciência. Mas o que estamos querendo dizer quando falamos em consciência?

Como muitas outras palavras, não é possível defini-la de maneira suficiente e necessária, mas podemos apresentar alguns exemplos que demonstram do que estamos versando: quando acordamos de um sono sem sonhos e permanecemos acordados entramos num estado consciente; quando estamos sob efeito de uma anestesia geral ou estamos dormindo não estamos conscientes. Há níveis diferenciados de consciência, por exemplo, mesmo acordados passamos por momentos em que estamos mais despertos e outros momentos em que estamos num estado de sonolência ou desatenção; isso evidencia os graus de consciência que podemos ter. Nesse sentido, até mesmo os sonhos não são estados completamente inconscientes, mas são estados conscientes com menor intensidade e vividez que a consciência ordinária.

O fato de sermos conscientes, de instanciarmos estados mentais conscientes, é uma característica biológica ordinária do mundo, mas normalmente consideramos quase impossível que assim seja, dadas as dificuldades para enquadrá-la no estudo científico como o restante do mundo. Por isso, a consciência não era tida como algo que fazia parte do mundo natural, e sendo assim, não foi estudada. Foi ignorada ou desconsiderada pelos filósofos da tradição materialista, que têm medo de falar nela, achando que precisam aceitar o dualismo. Entretanto, o estudo da consciência não implica em aceitarmos o dualismo, justamente porque ela faz parte do mundo natural.

É preciso remover os obstáculos criados, que impediam a situação da consciência no mundo físico, uma vez que a consciência, mesmo com todos os seus aspectos qualitativos, é um fenômeno biológico como qualquer outro. Trazer a consciência para o mundo das explicações científicas significa situá-la frente às teorias amplamente aceitas. Dentre essas teorias largamente difusas e fundamentais na nossa compreensão do mundo - que não podem ser ignoradas por qualquer pessoa razoavelmente bem instruída - estão a teoria atômica e a teoria 
da evolução. Cumpre ressaltar que essas teorias são complementares e uma é aceita porque é condizente com a outra. Juntas elas formam, em linhas gerais, a nossa compreensão de mundo. Sendo assim, temos que situar a consciência dentro dessa compreensão de mundo, ou seja, considerando a teoria atômica e a teoria evolutiva da biologia.

Para a teoria atômica o nosso mundo é inteiramente constituído de "partículas físicas", embora não seja muito exato falar em partículas, já que as partes elementares do mundo físico somente são compreendidas como pontos de massa e energia e não como entidades espaciais contínuas, ou seja, essas partes elementares comportam-se mais como onda que como partícula. Segundo Searle, o principal que precisamos deter da teoria atômica no intuito de explicarmos a consciência, além de que os grandes sistemas são formados por sistemas menores, é o seguinte: muitos aspectos dos grandes sistemas podem ser causalmente explicados a partir do comportamento dos sistemas menores.*

A teoria evolutiva baseia-se no fato de que, no processo reprodutivo dos seres vivos, aqueles que têm uma maior probabilidade de sobrevivência em relação ao seu ambiente têm também uma maior probabilidade de produzir mais ocorrências semelhantes, isto é, ocorrências com o mesmo genótipo. Em outras palavras, aquelas espécies que têm uma maior capacidade de adaptação a uma determinada realidade terão uma maior proficuidade reprodutiva: assim a espécie evolui. Os organismos provenientes da evolução são constituídos por sistemas menores, as células, essas que em alguns organismos desenvolvem subsistemas de células nervosas ditos como sistemas nervosos.

Dessa forma, alguns sistemas nervosos muito complexos - os cérebros - são capazes de causar e sustentar estados conscientes. Não se sabe, porém, o detalhe de como os cérebros causam a consciência, o que se sabe que ocorre em cérebros humanos e há fortes indícios que ocorra também nos cérebros de outros animais. ${ }^{8}$ Entretanto, no que diz respeito a esses outros seres vivos não sabemos até onde a consciência se estende para baixo na escala evolutiva, isto é, não sabemos exatamente quais os animais que realmente são conscientes.

Nessas palavras, Searle aponta o que entende por consciência e sua origem: "Consciência, em resumo, é uma característica biológica de cérebros de seres humanos e

\footnotetext{
* No entanto, disso não decorre que Searle acredite que a mente possa ser estudada a partir de um estudo completo do cérebro, isto é, a partir do sistema que a produz. Ele defenderá que a mente não é passível de redução. Nem mesmo uma ciência perfeita do cérebro seria capaz de possibilitar uma redução entre cérebro e consciência.

${ }^{8}$ Cf. SEARLE, J. A Redescoberta da Mente. São Paulo: Martins Fontes, 1997, p. 133.
} 
determinados outros animais. É causada por processos neurobiológicos, e é tanto uma parte da ordem biológica natural quanto quaisquer outras características biológicas, como a fotossíntese, a digestão ou a mitose."9

Portanto, é possível relacionar a consciência com a nossa imagem de mundo, levando em consideração suas duas teorias mais básicas: a teoria atômica e a teoria da evolução. Concluindo, essa é a síntese do raciocínio de Searle:

[...] o universo é constituído de partículas. Estas partículas estão organizadas em sistemas. Alguns desses sistemas são vivos, e esses tipos de sistemas evoluíram por longos períodos de tempo. Entre eles, alguns desenvolveram cérebros que são capazes de causar e sustentar consciência. Consciência é, assim, uma característica biológica de determinados organismos exatamente no mesmo sentido de "biológico" em que fotossíntese, mitose, digestão e reprodução são características biológicas de organismos. ${ }^{10}$

Assim, vemos que nosso autor entende que a consciência é “... uma particularidade fenotípica evoluída de determinados tipos de organismos com sistemas nervosos altamente evoluídos." 11

Mas restam ainda outras perguntas: Por que a evolução produziu a consciência se é perfeitamente imaginável o mesmo comportamento ou um comportamento semelhante por parte de um zumbi inconsciente? Qual é a vantagem da consciência nos seres vivos? Será que pelo fato da consciência estar no mundo e poder ser enquadrada na nossa visão científica deste, os estados mentais conscientes são fenômenos biológicos assim como os outros? Será que a consciência não possui características especiais que não são encontradas em outros fenômenos naturais? Isso tudo é o que veremos adiante.

\section{CONSCIÊNCIA E A VANTAGEM SELETIVA}

Por que razão teria a evolução produzido a consciência, que nos permite ter um comportamento consciente? Segundo Searle, a resposta é que a consciência nos dá poderes de discriminação muito maiores do que teriam os mecanismos inconscientes. Isso porque, como afirma nosso autor, “... podemos dizer que na percepção consciente o organismo tem representações causadas por estados de coisas no mundo, e, no caso de ações intencionais, o

\footnotetext{
${ }^{9}$ Id.

${ }^{10}$ Ibid., p. 137.

${ }^{11}$ Ibid., p. 134.
} 
organismo provoca estados de coisas no mundo através de suas representações conscientes." 12 A consciência facilita a organização das relações entre o organismo e o ambiente.

Além disso, o comportamento consciente normal tem um grau de flexibilidade e criatividade que está ausente em comportamentos inconscientes. Por exemplo: quando estamos a fazer uma atividade que é rotineira e corriqueira, se o nosso comportamento fosse inconsciente jamais poderíamos usar de criatividade em tal processo, mas como nosso comportamento é consciente, há sempre a possibilidade de que haja flexibilidade e criatividade nessa atividade rotineira que estamos a fazer. Essa é a tese que Searle pretende defender como vantagem evolutiva da consciência: a criatividade e flexibilidade do comportamento consciente.

\section{CONSCIÊNCIA E SUBJETIVIDADE}

Vimos que nossos estados mentais têm uma característica essencial: são conscientes; e a origem dessa consciência pode ser perfeitamente enquadrada na visão científica de mundo que possuímos, isto é, o fato de sermos conscientes é compatível com as grandes teorias da Física e da Biologia predominantes. Não há necessidade, portanto, de apelar para o dualismo.

Contudo, além de serem conscientes, os estados mentais possuem a característica de serem subjetivos, o que torna seu estudo muito mais complexo que o estudo da biologia de uma planta, por exemplo, ou até mesmo das partículas constitutivas de uma entidade física qualquer. A consciência é subjetiva e essa característica traz enormes dificuldades para o estudo científico dos estados mentais, já que a ciência é objetiva. Como afirma Searle: “... não podemos atingir a realidade da consciência da forma que, utilizando a consciência, podemos atingir a realidade de outros fenômenos."13

Para John Searle, o grande erro da Filosofia da Mente contemporânea, como rapidamente já falamos, é tentar estudar os estados mentais aliando-os ao comportamento consciente. Ela fez isso porque o comportamento consciente é objetivo e procuramos um conhecimento objetivo. Mas, ao tentar estudar os estados mentais dessa forma acabamos empobrecendo-os, ou seja, ignorando seus aspectos puramente livres, qualitativos e subjetivos.

Podemos sentir as nossas alegrias, mas quando tentamos observar a alegria do outro, o que percebemos é somente o comportamento consciente dele e não propriamente o que ele está

${ }^{12}$ Ibid., p. 158.
13 Ibid., p. 143.

Complexitas - Rev. Fil. Tem., Belém, v. 1, n. 2, p. 65-82, jul./dez. 2016 - ISSN: 2525-4154 
sentindo. Quando tentamos observar a consciência de uma pessoa o que conseguimos observar são as relações entre a consciência, o comportamento, a estrutura e o ambiente. A dor que sentimos não é igualmente acessível a qualquer observador: é possível que façamos uma transfusão de sangue ou até mesmo de coração, mas nunca de uma dor. Nunca poderemos saber com exatidão a dor que o outro está sentindo, pois até mesmo o seu comportamento, que supostamente manifesta a dor, pode ser uma farsa. Em outras palavras: vemos o mundo que nos rodeia sob o nosso ponto de vista. Portanto, a ontologia do mental é uma ontologia de primeira pessoa e disso decorre que a consciência não pode ser conhecida por outros da mesma forma que acontece com outros fenômenos biológicos.

Entretanto, Searle vai além afirmando que nossos estados subjetivos além de não poderem ser conhecidos por outros também não podem ser conhecidos pela introspecção. Não há, portanto, o acesso privilegiado. Esse acesso privilegiado é a idéia que sugere que a consciência é uma sala privativa dentro da qual somente nós mesmos podemos entrar. Contudo, tal acesso, segundo nosso autor, é impossível porque para haver algo a que tivéssemos acesso privilegiado, teria que ser diferente do espaço que estivéssemos a penetrar; seria necessária a distinção de três elementos: eu mesmo; o ato de entrar e o espaço que se está entrando. Tal impossibilidade de se conhecer a própria consciência se dá porque no processo de introspecção não há distinção entre a observação e a coisa observada, entre e percepção e o objeto percebido.

A introspecção de um estado consciente é ela mesma esse estado consciente.

\section{CONSCIÊNCIA E INTENCIONALIDADE}

Estamos apresentando alguns diferenciais que a consciência como noção central do estudo da mente possui. Falamos que os estados conscientes são subjetivos e não são passíveis de um estudo de terceira pessoa. Além disso, alguns estados conscientes são intencionais. Versaremos agora sobre a intencionalidade exibida por esses estados.

Para o autor de A Redescoberta da Mente, a intencionalidade é aquela propriedade de muitos estados e eventos mentais pela qual esses são dirigidos para, ou acerca de, objetos e estados de coisas no mundo. Por exemplo: quando temos uma crença essa deve ser uma crença de que determinada coisa é desta ou daquela forma; se temos um desejo, esse deve ser um desejo de fazer alguma coisa ou de que algo seja ou aconteça; e assim por diante. ${ }^{14}$ Por outro lado,

\footnotetext{
${ }^{14}$ Cf. SEARLE, J. Intencionalidade, São Paulo: Martins Fontes, 1995, p. 01
} 
formas não direcionadas como a ansiedade e a depressão não são intencionais. Isso quer dizer que a maior parte da consciência é intencional, mas não toda. Assim diz Searle: “... geralmente, em qualquer estado consciente, o estado é dirigido a uma coisa ou outra, ainda que a coisa à qual é dirigido não exista, e nesse sentido ele tem intencionalidade." 15

Nosso autor distingue intencionalidade intrínseca de intencionalidade atribuída. A intencionalidade de nossos estados mentais é intrínseca. Segundo ele, essa intencionalidade “... é um fenômeno que seres humanos e determinados animais possuem como parte da sua natureza biológica. Não é uma questão de como são tratados ou como concebem a si mesmos, ou de que forma preferem descrever-se a si mesmos." ${ }^{" 16}$ Nesse caso quando falamos sobre os estados mentais não estamos atribuindo crenças e desejos a estes a fim de compreendermos determinado comportamento, pelo contrário, trata-se de algo inerente ao próprio estado mental. Por exemplo: "estou com sede"; essa expressão indica um desejo de beber, algo real no próprio estado.

Para evidenciar o que é intencionalidade atribuída usemos alguns exemplos: "minha plantação de milho está com sede porque não choveu durante os últimos dias"; "o carburador do carro sabe enriquecer a mistura". Esses são casos de intencionalidade atribuída, ou seja, quando uma sentença é usada no sentido metafórico ou figurativo a fim de explicar o comportamento do agente em questão. Demonstra uma situação na qual nós teríamos aquela intenção; é uma descrição "como-se", ou seja, é uma situação na qual falamos da entidade "como-se-tivesse-intencionalidade".

\section{IRREDUTIBILIDADE DA CONSCIÊNCIA}

A mente - e como característica principal dessa a consciência - é produzida pelo cérebro, mas ela não pode ser reduzida a esse, isso porque ela é uma propriedade emergente. As propriedades emergentes são características de um determinado sistema que não podem ser concebidas meramente a partir da composição dos elementos e relações ambientais; elas têm que ser explicadas em termos das interações causais entre os elementos. Alguns exemplos de características ou propriedades emergentes são a liquidez, a solidez e a transparência. De igual forma, é a consciência, como afirma Searle:

\footnotetext{
${ }^{15}$ SEARLE, J. A Redescoberta da Mente. São Paulo: Martins Fontes, 1997, p. 188.
}

${ }^{16}$ Ibid., p. 118. 
[...] a consciência é uma propriedade causalmente emergente de sistemas. É uma característica emergente de determinados sistemas de neurônios da mesma forma que solidez e liquidez são propriedades emergentes de sistemas de moléculas. A existência da consciência pode ser explicada pelas interações causais entre elementos do cérebro no nível micro, mas a consciência em si não pode ser deduzida ou presumida a partir da mera estrutura física dos neurônios, sem alguma descrição adicional das relações causais entre eles. ${ }^{17}$

A consciência por ser causada pelo cérebro não possui vida própria, isto é, a idéia de que a consciência depois de produzida pelos neurônios possui vida própria é simplesmente falsa. No entanto, a fim de nos aprofundarmos mais na discussão, tendo em vista que o tópico da irredutibilidade da consciência é central em nosso debate, falemos sobre o que é especificamente o reducionismo, com intuito de demonstrarmos porque a consciência não é passível de tal projeto.

A idéia de redução baseia-se no fato de que determinadas coisas são nada exceto alguns outros tipos de coisas, o que leva a uma espécie de relação de identidade, ou seja, “A's podem ser reduzidos a B's, se A's forem nada exceto B's". Por exemplo: pela ciência pode-se demonstrar que genes consistem em nada exceto coleções de moléculas de DNA ou ainda que cadeiras são nada exceto coleção de moléculas.

$\mathrm{Na}$ ciência sempre que houveram reduções baseadas em processos causais, e que foram bem sucedidas, os fenômenos em questão sempre foram identificados com a sua causa. Por exemplo: as cores que eram definidas ostensivamente através do ato de apontar para exemplos, com a redução causal de fenômenos passaram a ser definidas em termos de refletâncias de luz, isto é, a cor foi reduzida ontologicamente a refletâncias de luz*; o mesmo aconteceu com o calor reduzido a movimento molecular; e com o som, reduzido a ondas propagadas no ar.

Assim a questão que se apresenta é a seguinte: tendo em vista que os fenômenos mentais conscientes são causados por processos neurobiológicos, é possível haver uma redução ontológica, de modo que a consciência seja nada exceto estes processos neurobiológicos? A resposta de John Searle a essa pergunta é não: “... mesmo uma ciência perfeita do cérebro não levaria a uma redução ontológica da consciência da forma que nossa ciência atual pode reduzir

\footnotetext{
${ }^{17}$ Ibid., p. 162.

* Mais propriamente a cor é reduzida à emissão de fótons. A cor vermelha, por exemplo, é referente à emissão de fótons de 600 nanômetros; portanto, vermelho é nada exceto emissões de fótons de 600 nanômetros.
} 
calor, cor ou som." ${ }^{18}$ Então porque na ciência essas reduções são possíveis e na consciência é impossível? Por que com o calor é possível uma redução e com a dor não é possível?

Porque nas reduções científicas, como no caso do calor, não interessa o aspecto subjetivo, mas as causas físicas subjacentes. A característica superficial do fenômeno é explicada a partir do comportamento dos elementos de uma micro-estrutura subjacente: a redução consistia em distinguir entre a aparência subjetiva e a realidade física subjacente. No entanto, nem mesmo a redefinição de um fenômeno elimina a aparência subjetiva dele: ela existe como sempre existiu, apenas não é interessante para a redução, que visa a objetividade.

Por outro lado, na consciência não há distinção entre aparência e realidade, e os fenômenos que mais interessam são as próprias experiências subjetivas. Assim diz Searle: “Onde a aparência está envolvida não podemos fazer a distinção entre aparência e realidade porque a aparência é a própria realidade."19 Para entendermos a impossibilidade de redução, basta imaginarmos o sentimento de uma dor: poderíamos até defini-la como padrões de atividade neural que causam sensações subjetivas de dor, no entanto, essa redução da dor a sua realidade física não reduz a experiência subjetiva da dor, que é o que realmente interessa. A consciência é irredutível porque é subjetiva. Disso decorre que nem mesmo uma ciência perfeita do cérebro seria capaz de possibilitar uma redução entre cérebro e consciência*. A tentativa de redução da consciência seria um projeto análogo à tentativa de deduzir "que música o rádio está tocando a partir do estudo das peças deste aparelho".

Eis como Searle se expressa:

[...] a consciência, como a solidez, é uma característica superficial de determinados sistemas físicos. Mas, diferentemente da solidez, a consciência não pode ser redefinida em termos de uma micro-estrutura subjacente, e as características superficiais, então, não podem ser tratadas como meros efeitos da consciência real sem que se perca o objetivo de ter o conceito de consciência em primeiro lugar. ${ }^{20}$

Mas a irredutibilidade da consciência não traz consigo consequiências profundas - de ordem metafísica - de modo que sejamos obrigados a aceitar o dualismo. A irredutibilidade não

\footnotetext{
18 Ibid., p. 168.

${ }^{19}$ Ibid., p. 176.

* Para Searle, um exemplo que auxilia na compreensão do aspecto irredutível da consciência é o apresentado Frank Jackson que foi relatado rapidamente no primeiro capítulo, página 28: mesmo o conhecimento pleno das atividades neurais não seria capaz de explicar os fenômenos mentais.

${ }^{20}$ Ibid., p. 177.
} 
implica numa distinção em nossa estrutura da realidade: a consciência faz parte do aparato fundamental da realidade e pode ser encaixada em nossa concepção global do universo. A única conseqüência é que, dada a existência da consciência e os seus aspectos subjetivos e qualitativos, ela não pode ser reduzida, da maneira que fazemos reduções.

Para nosso autor, a consciência é um estranho e maravilhoso fenômeno, com o qual devemos ficar assombrados, justamente pelo fato de que processos evolutivos produziram sistemas nervosos capazes de sustentar estados conscientes subjetivos e qualitativos, que são também irredutíveis às suas causas.

\section{ESTRUTURA DA CONSCIÊNCIA}

Apresentamos até aqui as principais propriedades da mente segundo nosso autor. Dissemos primeiramente que os processos mentais são causados pelo cérebro e têm lugar nele. Argumentamos, além disso, que a maioria dos estados mentais são intencionais intrinsecamente; que são subjetivos, qualitativos, fato esse que dificulta o seu estudo. Falamos que a característica central da mente é a consciência - já que a partir dela compreendemos as demais características - e que essa é uma propriedade emergente dos processos neurais, não redutível a esses, tendo em vista que mesmo a ciência perfeita do cérebro não seria capaz de explicar satisfatoriamente os fenômenos mentais subjetivos. Em outras palavras, dissemos que, no tocante aos estados mentais conscientes, não há como distinguir entre aparência subjetiva e realidade objetiva, como acontece nas reduções científicas, porque a aparência - a sensação subjetiva - é a própria realidade. Falamos ainda: que a consciência é um produto da evolução; assumir a sua existência não implica em aceitarmos o dualismo; a consciência é uma vantagem seletiva, já que o comportamento consciente tem a vantagem de possibilitar a flexibilidade e a criatividade nas ações.

Contudo, além dessas características existem outras que passaremos a apresentar adiante e que nos possibilitam formar pré-teoricamente uma estrutura da consciência.

Em primeiro lugar, a consciência humana é manifestada por um limitado número de modalidades, o que Searle chama de modalidades finitas. Isso significa que a consciência sempre se refere a objetos ou situações provenientes dos sentidos (visão, tato, paladar, olfato, audição e alguns consideram além desses, o sentido de equilíbrio), das sensações corporais e do fluxo de pensamento. Não há como estar consciente de outras realidades a não ser dessas. A 
consciência dos elementos dos sentidos é simples: os sentidos são a porta de entrada para aquilo que estaremos conscientes, por exemplo, quando enxergamos um animal, estamos conscientes de que aquele animal está a nossa frente: a visão foi o sentido utilizado. Quanto às sensações corporais, estas não se referem somente às sensações físicas óbvias, como as dores, mas também do sentimento do próprio corpo, como por exemplo, a posição das pernas, dos braços ou sentimento do joelho. O fluxo de pensamento refere-se não exclusivamente a imagens e palavras, mas também a sentimentos que podem estar relacionados a essas imagens ou palavras: por exemplo, quando lembramos de uma imagem de nossa infância, normalmente ela vem acompanhada de um sentimento, que pode ser alegria, tristeza, raiva, saudade, etc. O mesmo pode acontecer quando pensamos numa determinada pessoa.

A unidade é também uma característica dos estados conscientes. Para explicar essa característica usemos um exemplo: se estivermos numa sala onde há sofá, mesa de centro, estante, algumas folhagens, entre outras coisas e estamos vestidos com camisas floridas, todos esses elementos farão parte de um único evento consciente. A unidade nos eventos conscientes existe em duas dimensões: unidade vertical e unidade horizontal. Essa última espécie de unidade se refere a nossa memória curta, ou seja, a capacidade de unificar as experiências conscientes em curtos períodos de tempo; trata-se do presente recordado. Por exemplo: quando falamos uma sentença longa conseguimos nos lembrar daquilo que dissemos no início da sentença, mesmo sem estar dizendo ou pensando nela. A unidade vertical é uma questão de estar ciente simultaneamente de todas as diversas características de qualquer estado consciente; o primeiro exemplo dado (referente à sala) ilustra essa capacidade, ou seja, a de unificar todos os elementos presentes numa experiência consciente.

Já falamos sobre a intencionalidade - que também é uma característica - contudo, podemos acrescentar que, segundo Searle, “... somente um ser que pudesse ter estados intencionais conscientes poderia ter estados intencionais de algum modo e todo estado intencional inconsciente é pelo menos potencialmente consciente."21 Há, portanto, uma conexão entre consciência e intencionalidade. ${ }^{*}$ Isso implica que o estudo da intencionalidade

\footnotetext{
${ }^{21}$ Ibid., p. 190.

* Para Searle, os funcionalistas - como Daniel Dennett - cometem um grave erro quando procuram separar os estados intencionais da consciência: eles fazem isso porque não conseguem lidar com a consciência, com os qualia, e, portanto, consideram estes como não importantes.
} 
não pode ser desvinculado da consciência, e evidencia aquilo que vimos dizendo desde o início de nosso estudo: que a consciência é a noção central no estudo da mente.

Também já discursamos sobre a subjetividade dos estados conscientes, subjetividade esta que envolve necessariamente o aspecto de 'sentir-se-como' desses estados. O embaraço filosófico no estudo da consciência é devido, mais do que qualquer outra coisa, ao seu aspecto subjetivo.

A experiência consciente tem também uma estrutura de figura-fundo, isto é, tudo aquilo que focalizamos com a nossa atenção estará contra um pano de fundo que não é o centro da atenção. Por exemplo: se enxergarmos uma xícara, a enxergamos contra o pano de fundo da mesa; se enxergarmos a mesa, a enxergamos contra o pano de fundo do chão; esse por sua vez contra o pano de fundo da sala; e assim até os limites do nosso campo visual. Disso decorre que nossas experiências são sempre estruturadas, organizadas.

Outra característica dos estados conscientes é o aspecto da familiaridade. Este quer dizer que as coisas, lugares, cenas, pessoas, por mais estranhos que possam ser, sempre contêm aspectos que são familiares, e isso impede que a experiência consciente seja uma confusão. A familiaridade obviamente possui escalas, ou seja, uma determinada coisa pode ser mais familiar que outra.

O transbordamento é uma característica dos estados conscientes que diz respeito ao fato de que esses geralmente se referem a algo mais que seu conteúdo imediato. Por exemplo: quando olhamos para a janela e vemos as árvores, um campo e um lago, se nos solicitassem que descrevêssemos o que estávamos vendo certamente a resposta seria extensamente ilimitada, uma vez que podemos relacionar as árvores não somente como árvores, mas como árvores semelhantes a outras que conhecemos; a paisagem como um todo poderia evocar-nos outras imagens, e assim por diante. A característica do transbordamento significa que uma experiência consciente não está limitada nela mesma.

Quando estamos conscientes, o estamos de um número muito grande de coisas, algumas que não estamos atentos e outras que são objetos de nossa atenção. Há na consciência, portanto, o aspecto de centro e periferia. Isso é ilustrado nos exemplos que seguem. Quando dirigimos um automóvel estamos conscientes do que fazemos, mas podemos estar com a nossa atenção voltada para uma pessoa doente que estamos indo visitar: o centro de nossa atenção é a pessoa doente e não o ato de dirigir, que ocupa a periferia da nossa consciência; é errado, porém afirmar 
que estamos dirigindo o carro inconscientemente. Outro exemplo é quando vamos nos sentar numa cadeira: esse ato ocupa o centro da nossa consciência, entretanto, depois que sentamos, simplesmente desviamos nossa atenção para outra coisa qualquer.

Outra característica dos estados conscientes é a seguinte: mesmo que não estejamos pensando no dia do mês em que estamos, na cidade em que vivemos, no país do qual fazemos parte, que nome possuímos, etc., todas essas situações fazem parte de nossos estados conscientes. Isso significa que qualquer estado de consciência é localizado, espacialmente, temporalmente, socialmente, biologicamente, etc. Contudo, a localização em si não pode ser completamente abarcada como objeto da consciência. $\mathrm{O}$ aspecto da localização fica evidente nos casos de interrupção desta: quando não conseguimos o dia, a hora ou o lugar em que estamos, logo somos invadidos por um sentimento súbito de desorientação.

O humor fornece a tonalidade ou a cor que caracteriza o conjunto de um estado consciente ou uma seqüência de estados conscientes e é uma característica de estados conscientes, mesmo não sendo intencional. Outro aspecto dos estados conscientes é a dimensão prazer e desprazer: todo estado consciente possui a característica de ser mais ou menos prazeroso.

\section{CONSIDERAÇÕE FINAIS}

No tocante a concepção de mente em John Searle, concluímos que, para esse autor, a mente é uma característica do cérebro, assim como a liquidez é uma característica da água, que tem como propriedade central a consciência.

Vimos também que, para Searle, assumir a existência da mente não implica em aceitarmos o dualismo, já que a mente (ou a consciência) faz parte do mundo natural e é um produto da evolução, uma vantagem seletiva que torna nossas ações dotadas de flexibilidade e criatividade.

Os processos mentais são causados pelo cérebro e estão localizados nele. Os estados mentais são subjetivos e qualitativos - fato que dificulta seu estudo - e maioria deles são intencionais. Essa intencionalidade é uma propriedade intrínseca e distintiva dos estados mentais.

A mente é uma propriedade emergente dos processos neurais que não pode ser reduzida e esses porque a aparência subjetiva é a própria realidade objetiva. Para Searle, a mente é uma 
característica de sistemas biológicos (de seres humanos e de alguns outros animais) e não pode ser instanciada em outros artefatos não biológicos, por isso sua tese é denominada de naturalismo biológico.

\section{REFERÊNCIAS}

BLACKBURN, S. Dicionário Oxford de Filosofia. Rio de Janeiro: Jorge Zahar ed., 1997. 437p. COTTINGHAM, J. Dicionário Descartes. Rio de Janeiro: Jorge Zahar ed., 1995. 171p.

CHURCHLAND, P. M. Matéria e Consciência: uma introdução contemporânea à filosofia da mente. São Paulo: Unesp, 2004. $286 \mathrm{p}$.

LYCAN, W.G. Filosofia da mente. In: BUNNIN, N. e TSUI-JAMES, E.P. (org) Compêndio de Filosofia. São Paulo: Loyola, 2002. p. 163-191.

SEARLE, J. R. A Redescoberta da Mente. São Paulo: Martins Fontes, 1997. 379p.
Intencionalidade, São Paulo:

Martins Fontes, 1995, 390p.

.Mentes, Cérebros e Programas. In: TEIXEIRA, J. F. Cérebros, Máquinas e Consciência: uma introdução á filosofia da mente. São Carlos: EDUFSCar, 1996, p. 6193.

. O Mistério da Consciência. São Paulo: Paz e Terra, 1998. 229p.

. Mente, Cérebro e Ciência. Lisboa: Edições 70, 1984. 125p.

TEIXEIRA, J.F. Mente, Cérebro e Cognição. 2. ed. Petrópolis: Vozes, 2000. 197p.

CARDOSO, Matêus Ramos. A Concepção de Mente em John Searl. Complexitas - Rev. Fil. Tem., Belém, v. 1, n. 2, p. 38-82, jul./dez. 2016. Disponível em:< http://www.periodicos.ufpa.br/index.php/complexitas/article/view/3753>. Acesso em: 20 abr. 2017. 